\title{
Higher education institutions energy efficient methods of functional planning solution
}

\author{
Gelena Kovalska, Irina Bulakh, Margaryta Didichenko*, Olena Kozakova, and Olena Chala \\ Kyiv National University of Construction and Architecture, 31 Povitroflotskyi Ave., Kyiv, 03680, Ukraine
}

\begin{abstract}
The article determines that the priority factor of energy efficiency at the design stage is the optimal functional and planning solution of educational buildings; established architectural and planning techniques aimed at improving energy efficiency of higher education institutions, including compaction of educational institutions, clear zoning, implementation of compact architectural and planning solutions for educational buildings and structures, blocking in one or adjacent areas of several free economic cooperation with cooperative use of engineers increasing the number of storeys of buildings, the use of underground space and landscaping in the architectural and planning solution of buildings.
\end{abstract}

\section{Introduction}

In the process of long-term development in the leading cities of Ukraine, an extensive network of higher education institutions (HEIs) of various profiles has been formed, which significantly affects urban planning activities, architectural and compositional qualities of buildings, energy efficiency of buildings $[1,2,7]$.

The main trends of energy saving are: introduction of fundamentally new types of building structures, use of effective thermal insulation materials, use of solar, wind, earth energy, use of ground heat for heating and cooling of buildings with heat pumps, energy efficient external enclosing structures [12-17]. However, the priority factor of energy efficiency at the design stage is the optimal functional and planning solution of the educational institutions buildings, as well as the appropriate architectural and planning techniques aimed at improving the energy saving of free economic zones.

\section{Results}

Analysis of the practice of operation of higher education institutions shows that the development of educational facilities is significantly complicated by the lack of territorial resources and significant energy intensity of educational buildings, especially laboratory and educational purposes. Progressive domestic and foreign experience in forming a network of higher education institutions shows that the most realistic direction for optimizing the development of higher education is the consolidation of educational institutions, clear zoning, implementation of compact architectural and planning solutions for educational buildings and structures $[3-5,7$, 8].

According to the pedagogical requirements, the territory of the Free Economic Zone should be built up comprehensively. Educational, research, household, residential and other buildings that provide different directions, forms and methods of educational work should be placed on the allocated area. Buildings need to be functionally connected with each other and with other structural elements of the city. The site should provide conditions for the gradual development of free economic zones and provide an opportunity to develop training areas in the future $[4,5,6,11]$.

The main scientifically substantiated and tested by project practice principle of planning decisions of higher education institutions is the functional zoning of the territory. Areas of educational zones should be divided into the following main zones: educational, sports, residential, economic. Each of the marked zones, depending on the profile of HEIs and town-planning conditions, has the features. Thus, the training area may include research units and in this case it grows significantly and requires additional areas. In branch educational establishments of technical, agricultural, medical profile and others in the educational zone, as a rule, a large group of research and educational-production subdivisions is created, and in medical educational establishments - a subzone of treatment-and-prophylactic establishments.

The size of the territory for the construction of educational buildings depends on the size and profile of the free economic zone. Theoretical research has identified, and project construction practice has confirmed that the larger the number of university students, the more efficiently the territory is used.

The second direction of improving the construction of higher education institutions is the blocking of several free economic zones in one or adjacent territories under the condition of cooperative use of engineering communications, some buildings of educational and teaching-auxiliary purpose. Cooperation is especially

\footnotetext{
* Corresponding author: didichenko.margo@gmail.com, didichenko.mo@knuba.edu.ua
} 
expedient at homogeneity of educational and production functions of the establishments forming a complex. In many cases, this allows for the organization of a single public service system, joint research and production and energy centers.

The main functional requirement of the cooperation is the intensive use of premises and territory, increasing the density of buildings at the maximum allowable load. Particularly effective joint operation of energy-intensive and large-sized training and laboratory equipment, experimental equipment, etc. When cooperating, homogeneous zones should be used as intensively as possible, reducing the total size of the territory compared to the normative ones [7].

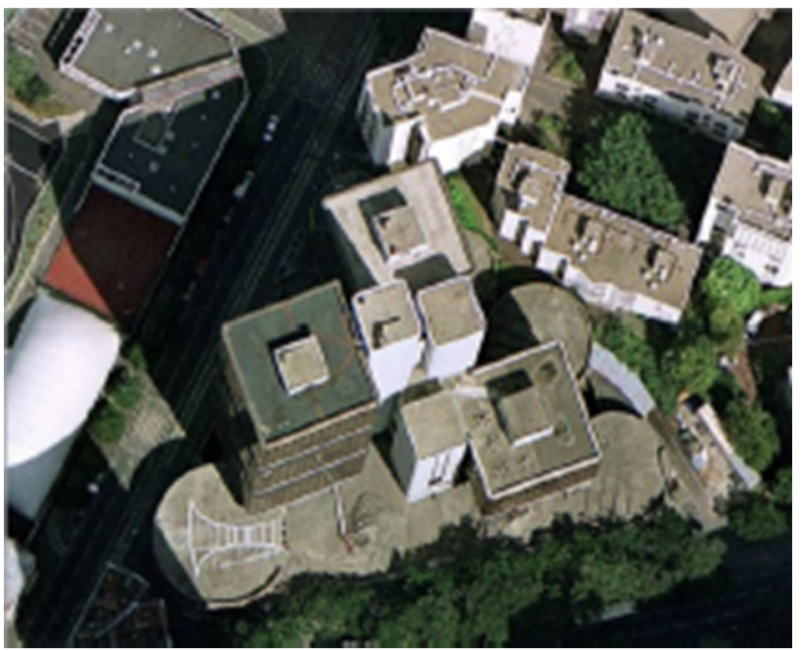

Fig. 1. University complex in the center of Paris, France.

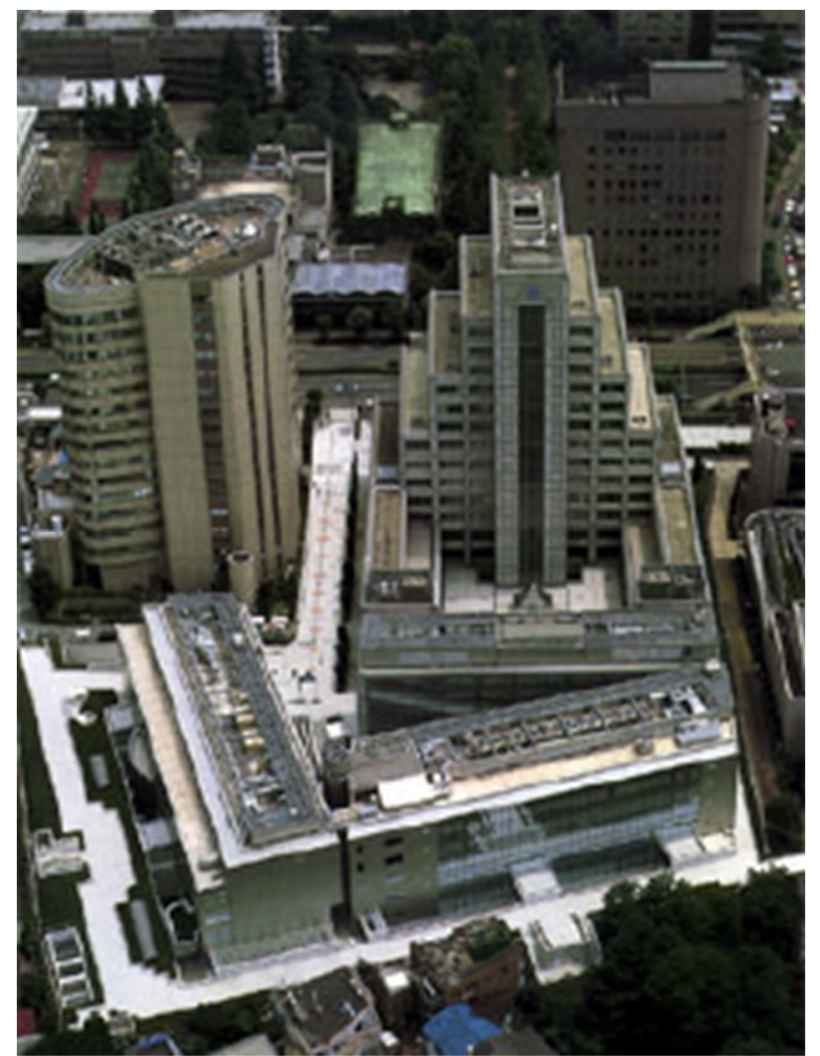

Fig. 2. University of Compacted Buildings, Tokyo, Japan.

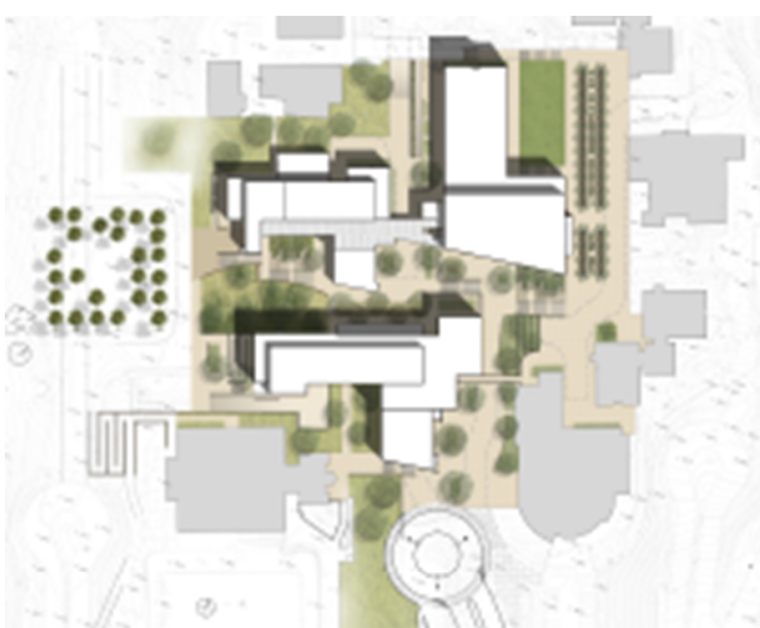

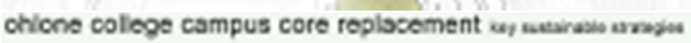

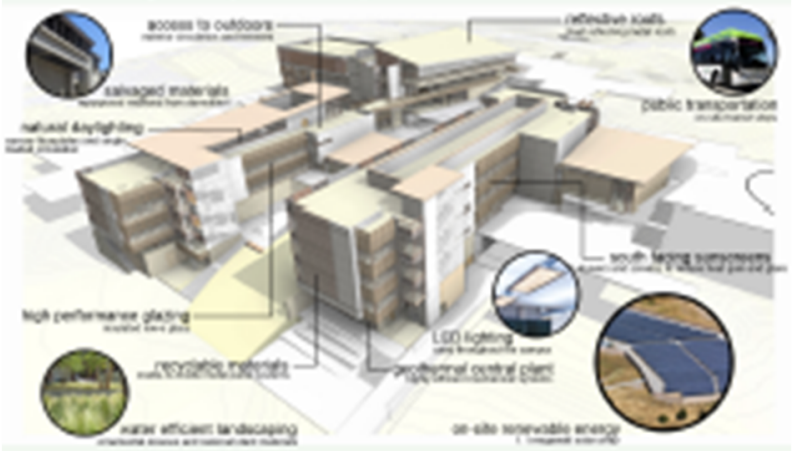

Fig. 3. Ohlone College Academic Core Buildings in Fremont, USA.

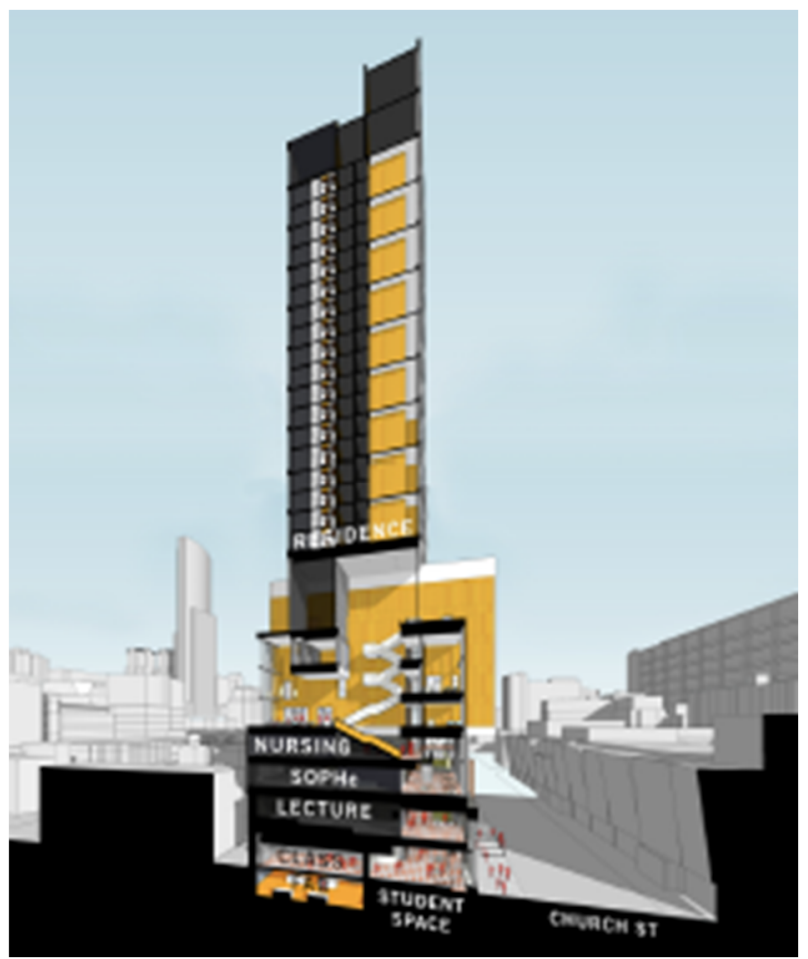

Fig. 4. Ryerson University Daphne Cockwell Health Sciences Comple in Toronto, Canada

An effective means of compacting the construction of higher education institutions is the use of compact architectural and planning solutions of educational 
buildings and increasing the number of storeys of buildings, especially student dormitories. In foreign practice, there are many examples of multi-storey buildings of compact structure both in the historical environment (Fig. 1, Fig. 2) and new solutions in developing territories (Fig. 3, Fig. 4) [1, 4, 19, 31, 32].

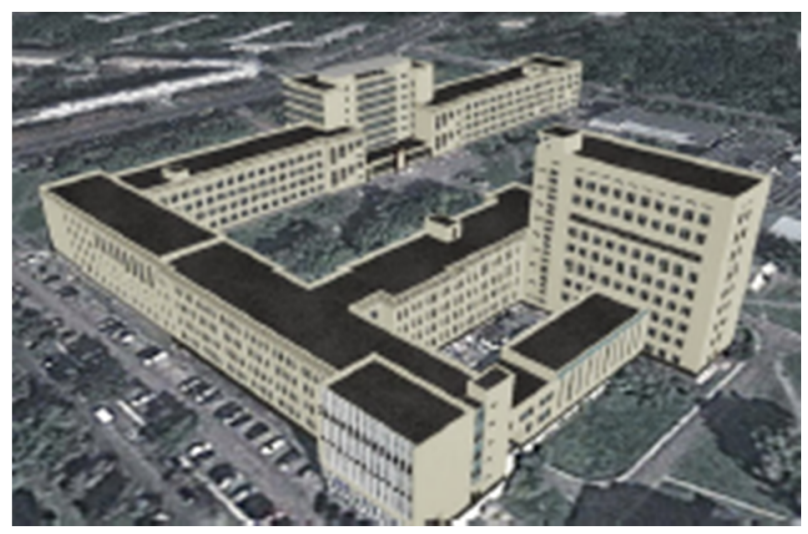

Fig. 5. 3D model of main buildings of the Kyiv National University of Construction and Architecture, Kyiv, Ukraine.

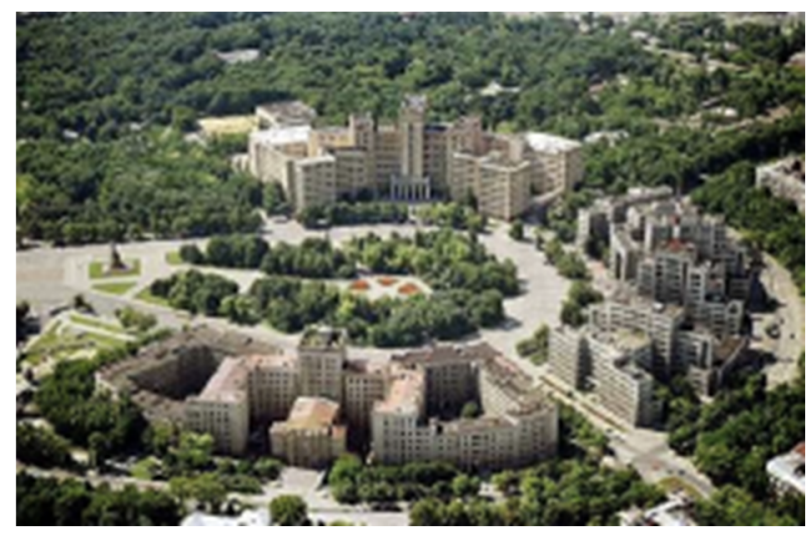

Fig. 6. Complex of Karazin Kharkiv National University, Kharkiv, Ukraine

In Ukraine, high-rise buildings are built and successfully operate in higher education institutions of Kyiv, Dnipro, Kharkiv, Donetsk, Odessa and other large cities with compacted buildings $[1,2,21]$. Much of the university complexes were built in the second half of the twentieth century, so most of these buildings have a high level of wear, both physical and moral. To increase their comfort and energy efficiency, large-scale reconstruction and renovation works are required (Fig. 5, Fig.6). The main directions of reconstruction should be based on the principles of introduction of resource-saving technologies, ensuring environmental safety. The requirement of compact placement of educational buildings is due not only to the need for rational use of land resources, but also the conditions of effective organization of the educational process, centralized maintenance of teaching aids, more intensive loading of educational premises, reduction of unproductive costs for moving between remote buildings. The total height of educational buildings, the number of floors are accepted depending on the functional requirements and urban conditions. According to the current regulations, educational buildings of higher educational institutions and institutes of advanced training are recommended to provide a height from the ground level, determined at the entrance to the house, to the floor of the top floor within $26.5 \mathrm{~m}$. increasing the number of storeys of buildings [5].

In recent years, the construction and construction of several higher education institutions with high-rise buildings and dormitories have been designed and started. The universities of the new generation include the Open International University of Human Development "Ukraine", designed in the research and design architectural bureau "LICENZiARCH". The density of the building led to an increase in the height of educational buildings to 18-21 floors. Increasing the number of storeys did not prevent the creation of all the necessary conditions for effective student learning. This is one of the few higher education institutions in Ukraine that provides comfortable training for professionals with disabilities. Multi-storey educational buildings are blocked with the educational-administrative building and a group of dining room and concert hall. The first floors of the multifunctional volume occupy the premises of general university use. The educational premises of some departments are located on the upper floors. All rooms are connected by stairs and special elevators, which meets the technological needs, fire safety requirements and ensures the movement of people with special needs (Fig. 7). Also, this design bureau made a conceptual proposal for the renovation of the Kyiv National University of Construction and Architecture territory in Kyiv, which provided for the consolidation of the central core and the creation of additional educational and residential buildings (Fig. 8).

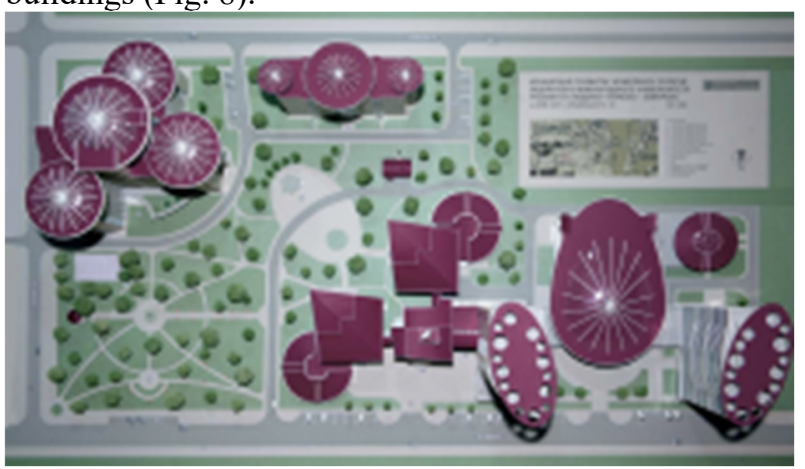

$\mathrm{a}-$ model of existing complex

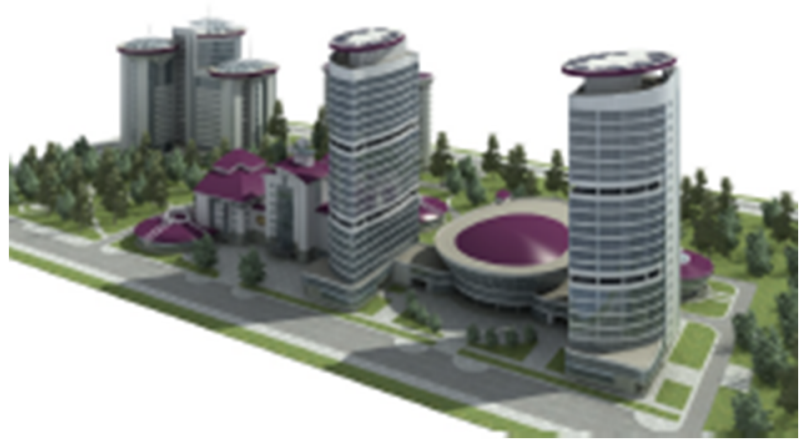

b - project proposal

Fig. 7. Open International University of Human Development "Ukraine", Kyiv, Ukraine. 


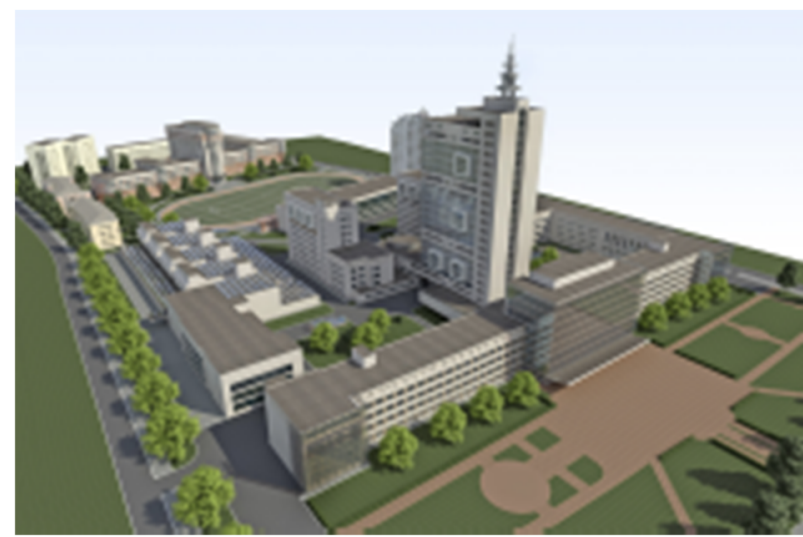

Fig. 8. Project proposal for Kyiv National University of Construction and Architecture, Kyiv, Ukraine.

The requirement of compact placement of educational buildings is due not only to the need for more rational use of land resources, but also the conditions of effective organization of the educational process, centralized maintenance of technical means of training, intensive loading of educational premises, reducing the length of utilities, heating and electricity. To seal the building, assembly halls, club rooms, libraries, student cafes and canteens are recommended to be blocked on the common territory, thus creating a training and community center. In the conditions of compacted building, if it is impossible to form a public center near educational buildings, part of the club premises, catering establishments, can be located in a residential area [6]. For example, the new campus building at the University of Cincinnati is creating a multi-functional cultural and learning center for collaboration that is not available in older buildings (Fig. 9).

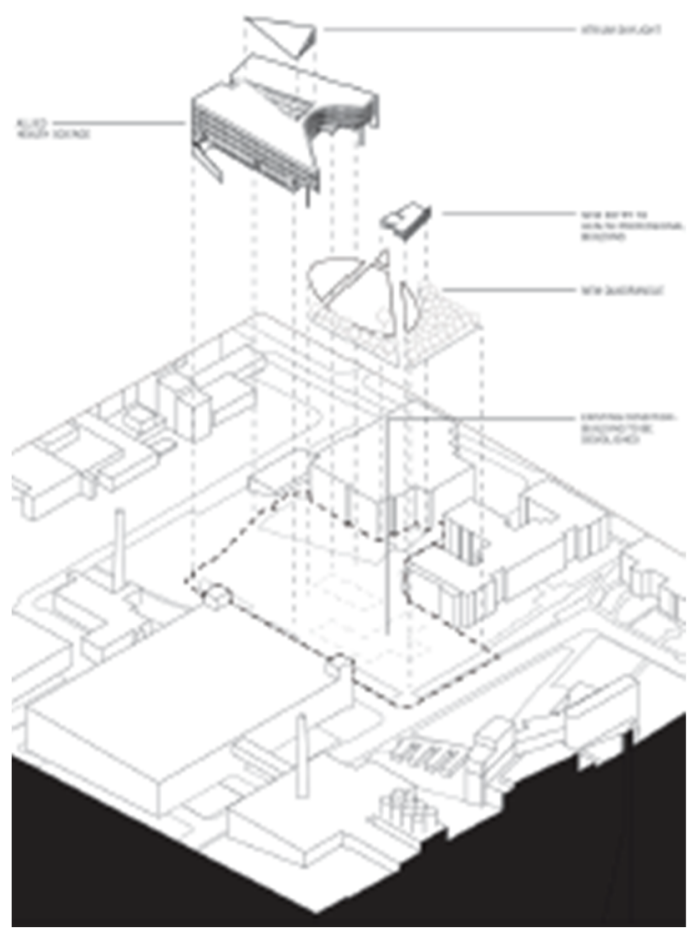

Fig. 9. University of Cincinnati Health Sciences Building, Cincinnati, USA.
Blocks of lecture halls, libraries, assembly halls, dining rooms can be compactly placed in buildings up to 4 floors. In large educational institutions for 5,000 students and more, libraries, club rooms, student canteens should be moved to separate buildings. For a more compact building should also take into account the possibility of using underground space (Fig. 10). In the basement and basement it is allowed to place: TV studios, bookstores, laboratories for the study of individual special projects, part of the premises of catering establishments, warehouses and technical premises. The principle of placement of administrative premises (administration) significantly influences the formation of the educational zone. In educational complexes with a contingent of more than 5,000 students, it is advisable to form a separate administrative and cultural center or block it with a library, assembly hall and other public facilities.

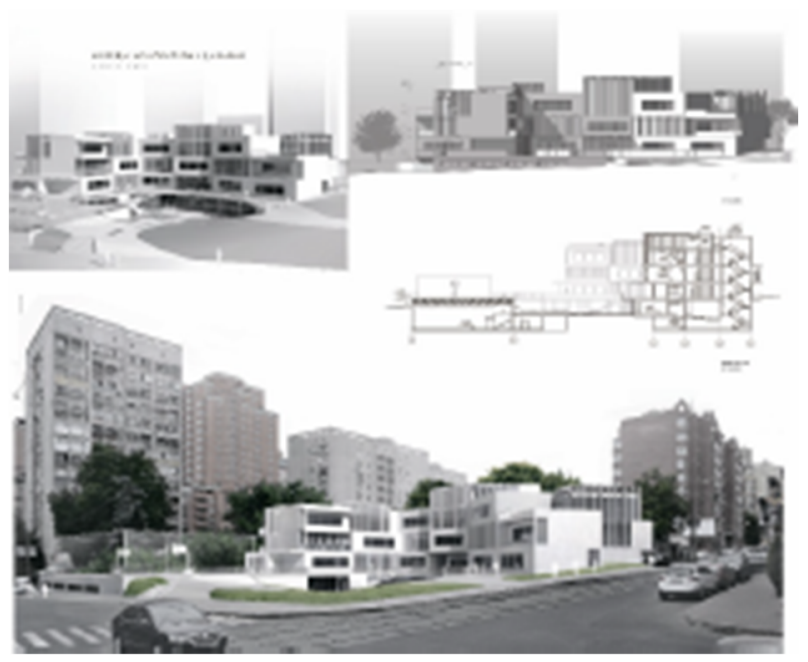

Fig. 10. Bachelor's degree "College of Architecture and Design in Kyiv", Art. Tolstikov T.O., head - Doctor of Architecture Kovalska G.L.

Energy-efficient methods include the use of landscaping in the architectural and planning solution of buildings. Currently, there are several areas in landscaping of university buildings: landscaping of roofs, landscaping of facades; landscaping due to new ecological materials [22-27]. In this aspect, the interesting building of the non-governmental women's university in Seoul - "Ewha Campus Complex" (Ewha Campus Complex, ECC), arch. Dominic Perrault, 2008 (Fig. 11). The roof of the campus was a garden, which protects the interior from the heat in summer and from the cold in winter. Increases the economy and practical use of rainwater - special tanks have been created for it, from where water is distributed for the operation of bathrooms $[10,12-14,33]$. A similar solution was applied in the design of a social and cultural center in the historic center of Paris (Fig. 12). The building is not only successfully integrated into the existing environment, but also creates an optimal microclimate both inside and outside [34]. 

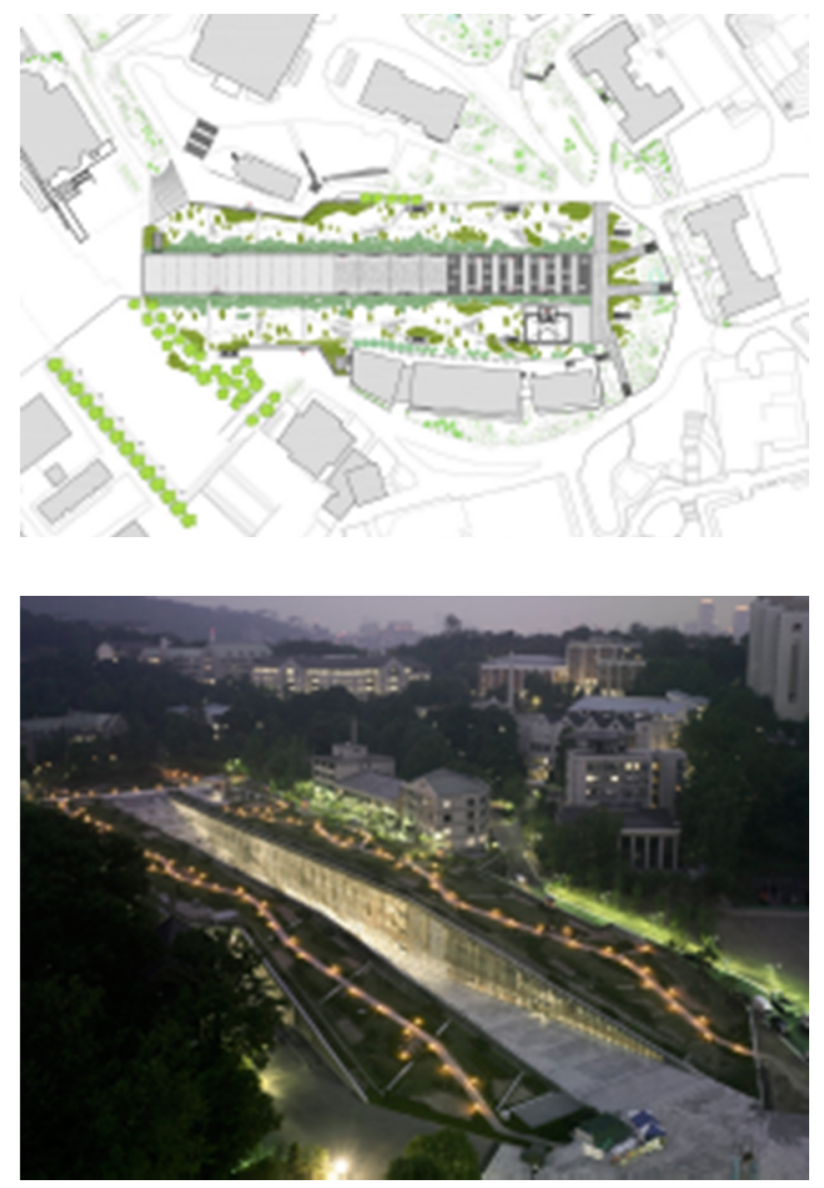

Fig. 11. Non-State Women's University (Ewha Campus Complex, ECC) in Seoul, South Korea.

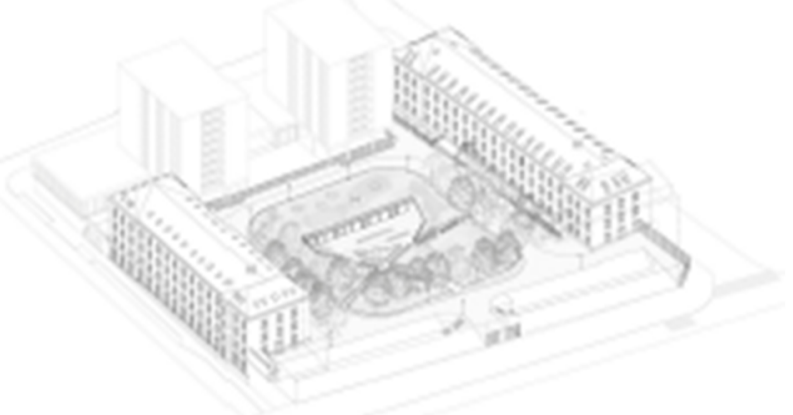

Fig. 12. Modernization of the Lourcine Barracks in the University of Law-Paris I, Paris, France.

The largest area and territory are needed by technical free economic zones due to the need to create auxiliary research units (19-20 square meters per 1 student). When blocking research groups of premises with the relevant departments and faculty blocks, the educational and research process is organized much more efficiently and the energy base is used more rationally. Only specialized research and production units with specific technology are recommended to be allocated and placed in the peripheral areas of the educational institution [2]. Calculations show that due to the compaction of buildings, the introduction of compact architectural and planning solutions can significantly reduce the territory of higher education institutions and reduce energy consumption by $20-30 \%$ without deteriorating the conditions of the educational process $[8,9]$.

One of the criteria influencing the energy efficiency of educational complexes is heat loss, which is carried out through the outer walls of the building. Compact architectural solutions, integration of buildings into complexes, blocking of building elements provide reduction of external contours of buildings in comparison with separately placed constructions. As an example, we can calculate the perimeter of the outer walls of two rectangular buildings with sides $(a, b)$ and $(c, d)$, located separately and locked into a single complex (Fig.13). The length of external walls of buildings at a separate arrangement is equal to the sum of their perimeters, namely: $2 a+2 b+2 c+2 d$. The length of the outer walls of the blocked complex is equal to: $2 a+2 c+b+d+(d-$ b) $=2 \mathrm{a}+2 \mathrm{c}+2 \mathrm{~d}$. These calculations show a reduction in the perimeter of the blocked buildings by $2 b$ and, accordingly, a reduction in heat consumption.
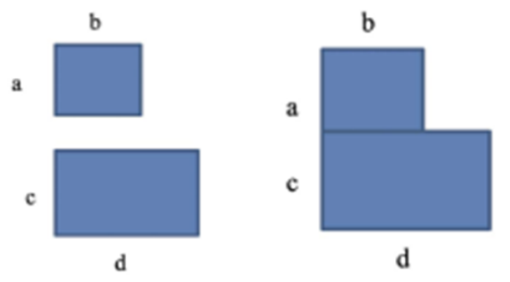

Fig. 13. The scheme of calculation of perimeter at blocking of buildings.

\section{Conclusion}

Energy efficiency is a necessary measure in the modern architecture of higher education institutions. The architect should think about creating an energy-efficient building at the design stage. The optimal functional and planning solution of buildings, the establishment of appropriate architectural and planning techniques can be called the primary factor in increasing its energy savings.

The article substantiates the importance of a compact architectural and planning solution as one of the important aspects of achieving the overall energy efficiency of the building.

\section{References}

1. S.M. Linda, Architectural Design of Public Buildings and Structures (National. Univ. Lviv Polytechnic, 2010)

2. G.N. Tsytovich, The higher educational institutions with the developing planning structure (Stroyizdat, 1982)

3. Ministry of Education and Science of Ukraine. https://mon.gov.ua (2021). Accessed 21 Mar 2021 
4. V.V. Kutsevich, L.Yu. Bridney, O.S. Rogozhnikov. Regulatory and methodical bases of architectural designing of public buildings and structures (KNUCA, 2016)

5. Buildings and structures. Educational institutions: $D B N \quad$ B.2.2-3:2018 (Ukrarhbudinform: State Committee for Urban Development of Ukraine, 2018)

6. Planning and development of territories: DBN A.2.212:2019 (Ukrarhbudinform: Ministry of Regional Development of Ukraine, 2019)

7. V.I. Yezhov. Architecture of public buildings and complexes (VISTKA, 2006)

8. G. Kovalska, I. Merylova, I. Bulakh, Urban Improvement of Comprehensive Schools and Out of School Educational Establishments in Ukraine. IJITEE $\quad \mathbf{8 ( 1 2 ) ,} \quad 1765-1770 \quad$ (2019). doi:10.35940/ijitee.L3229.1081219

9. G. Kovalska, V. Smilka, Construction management in Ukraine. IJITEE 9(1), 1593-1600 (2019). doi:10.35940/ijitee.A4563.119119

10. M. Orlova, V. Korsi, M. Brodach, Students campuses design. Energy efficiency and environmental friendliness. Sustainable Building Technologies 4, 36-43 (2018)

11. L.M. Kovalskij, Architecture of higher educational institutions. Universities of the $3 \mathrm{rd}$ millennium (Osnova, 2011)

12. Y. Tabunschikov, M. Brodach, N. Shilkin, Energyefficient high-rise building 3, 8 (2002)

13. Y. Tabunschikov, M. Brodach, Scientific principles of designing energy-efficient buildings. ABOK 1 (2008)

14. M. Spikman, D. Van Dijk. Comparison of the energy performance of buildings in the EU. Energy saving 5, 43-45 (2009)

15. I. Bulakh, M. Didichenko, O. Kozakova, O. Chala, Sustainable futures in the context of architectural design of hospitals. E3S Web of Conferences 166, 08001 (2020). doi:10.1051/e3sconf/202016608001

16. R. C. G. M. Loonen, M. Trčka, D. Costola, J. L. M. Hensen, Climate Adaptive Building Shells: State of the Art and Future Challenges. Renewable and Sustainable Energy Reviews 25, 483-493 (2013). doi:10.1016/j.rser.2013.04.016

17. R. Loonen, A. Khairulina, J. Hensen, Bioadaptive shell of buildings. High-tech buildings 3(3-3), 50-57 (2014)

18. V.V. Kutsevich. Formation of an architectural school. History, traditions, modernity (Lira-K, 2018)

19. New housing concepts, Leading International, Spain (2000)

20. K. Kropf. The handbook of urban morphology (Wiley, 2017)

21. The Open International University of Human Development 'Ukraine'. https://uu.edu.ua (2021). Accessed 21 Mar 2021
22. Architecturestudio.

http://www.architecturestudio.fr/en/projects/pacr1/u niversity residence.html (2021). Accessed 21 Mar 2021

23. E. Bjerring, Tietgen Dormitory. https://arcspace.com/feature/tietgen-dormitory/. Accessed 21 Mar 2021

24. Passive House Database. https://passivhausprojekte.de/index.php?lang=en\#d_ 3179. Accessed 21 Mar 2021

25. Roebuck Castle Student Residence, UCD / Kavanagh Tuite Architects. https://www.archdaily.com/187581/roebuck-castlestudent-residence-ucdkavanagh-tuite-architects. Accessed 21 Mar 2021

26. Ewha Womans University / Dominique Perrault Architecture.

https://www.archdaily.com/227874/ewha-womansuniversity-dominique-perrault-architecture. Accessed 21 Mar 2021

27. T. Rigg, UCD 'Passive House' Student Residences Roebuck Hall II. PLEA 25 (2008)

28. KNU students' dormitory site. https://studmisto.knu.ua/. Accessed 21 Mar 2021

29. KNUBA dormitory informations. http://www.knuba.edu.ua/?page_id=120. Accessed 21 Mar 2021

30. LP dormitory. hhttp://www.lp.edu.ua/node/296. Accessed 21 Mar 2021

31. CannonDesign. https://www.cannondesign.com. Accessed 21 Mar 2021

32. Perkins+Will. https://perkinswill.com. Accessed 21 Mar 2021

33. Dominique Perrault Architecture. http:// www.perraultarchitecture.com/en/homepage. Accessed 21 Mar 2021

34. Chartier Dalix Architectes. https://www.chartierdalix.com. Accessed 21 Mar 2021 